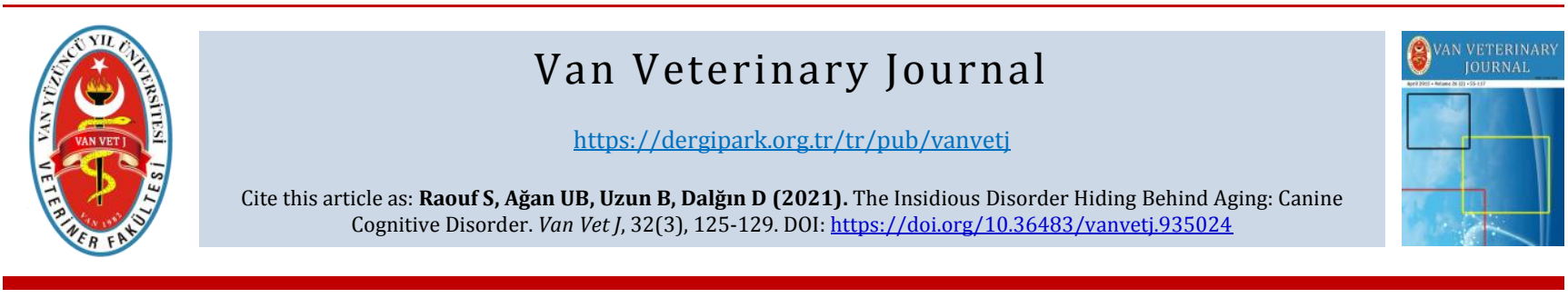

\title{
The Insidious Disorder Hiding Behind Aging: Canine Cognitive Disorder
}

 \\ Ondokuz Mayıs University, Faculty of Veterinary Medicine, Department of Internal Medicine, 55270, Samsun, Turkey \\ Received: 08.05.2021 \\ Accepted: 10.10 .2021
}

ABSTRACT Canine cognitive disorder (CDS) is a neurodegenerative, progressive, and irreversible disorder of senior dogs, generally over eight years old. CDS is characterized by a decrease in cognitive functions. Clinically significant changes in dog's behavior and daily routines including disorientation, decrease in social interactions, changes in sleep-wake cycles, loss of household habits, poor communication, increased anxiety, and changes in activity levels with the potential to create significant problems and discomfort in the lifestyle of the owners, deteriorating pet-owner attachment and generally be frustrating for the owner. The definite diagnosis depends on brain biopsies, and there is no confirmed clinical diagnosis method developed, meeting the whole criteria of CDS. The owner assessment using several scales available is the primary tool to rely on, which has a high potential to be subjective. Although it still has many dark sides, CDS is a disease with convenient diagnostic and therapeutic strategies available. Veterinarians need to consider this disease in geriatric patients and cooperate by increasing owner awareness, stopping or at least slowing down the disease in elderly dogs, and making the geriatric period more comfortable for both the dog and the owner. This review aims to introduce current information in the diagnosis and treatment of CDS.

Keywords: Cognitive behavioral therapy, Cognitive disorder, Cognitive dysfunction, Cognitive therapy, Dementia, Dogs.

öz

\section{Köpeklerin Yaşlanmaya Bağlı Bilişsel Bozukluğu}

Köpek bilişsel bozukluğu (CDS), genellikle 8 yaşın üzerindeki yaşlı köpeklerde görülen nörodejeneratif, progresif ve geri dönüşümsüz bir bozukluktur. CDS, klinik olarak bilişsel işlevlerde azalma, günlük rutinlerinde önemli değişiklikler ve davranışlarda oryantasyon bozukluğu, sosyal etkileşimlerde azalma, uyku-uyanma döngülerinde değişiklikler, ev alışkanlıklarının kaybı, zayıf iletişim, artan anksiyete ve aktivite düzeylerinde değişiklikler dahil olmak üzere değişiklikler ile karakterizedir. Bu değişiklikler sahiplerin yaşam tarzlarında önemli sorunlar, ciddi rahatsızlık oluşturma, köpek ve sahip arası iletişimin bozulması potansiyeli barındırmasının yanı sıra bazen köpek sahibi için dayanılmaz olma durumu vardır. Kesin tanı beyin biyopsilerine dayanmaktadır ve CDS'nin tüm kriterlerini karşılayan doğrulanmış bir klinik tanı yöntemi geliştirilmemiştir. Mevcut olan bir dizi ölçeğin sahiplerin görüşü doğrultusunda değerlendirilmesi, güvenilecek birincil araçtır ve öznel olma potansiyeli yüksektir. Hala birçok karanlık tarafı olmasına rağmen, CDS, kullanıșlı tanı ve tedavi stratejileri olan bir hastalıktır. Veteriner hekimlerin geriatrik hastalarda bu hastalığı göz önünde bulundurması ve sahiplerin hastalık konusunda farkındalığını artırarak iş birliği yapması, yaşlı köpeklerde hastalığı durdurması veya en azından yavaşlatması ve geriatrik dönemi hem köpek hem de sahibi için daha konforlu hale getirmesi önemlidir. Bu derleme, CDS'nin tanı ve tedavisinde güncel bilgileri sunmayı amaçlamaktadır.

Anahtar Kelimeler: Bilişsel davranış̧̧ı terapi, Bilișsel bozukluk, Bilişsel tedavi, Demans, Köpekler.

\section{INTRODUCTION}

Canine cognitive disorder (CDS) describes the progressive neurodegenerative disorder of older dogs due to a gradual decline in cognitive function in the veterinary literature. CDS is characterized by a decrease in cognitive functions and clinically significant changes in dog's behavior and daily routines due to progressive neurodegenerative changes in the cerebral cortex and hippocampus and affected dogs are generally over eight years of age
(Landsberg 2012). The awareness of the owners for pet health, the increase in pet household companionship, the advances in the veterinary field, and preventive medicine enabled a longer life span for pets. The prolongation of life brings along an increase in the incidence of geriatric problems and degenerative diseases (Landsberg 2012).

Changes associated with CDS are very likely to affect the dog-human bond, as pet owners are often unaware of the changes that come with aging. Considering that these 
changes include disorientation, decrease in social interactions, changes in sleep-wake cycles, loss of household habits, poor communication, increased anxiety, and changes in activity levels with the potential to create significant problems and discomfort in the lifestyle of the owners may be frustrating for some individuals (Rosado et al. 2012; Larsen and Farcas 2014).

Awareness of the disease and supportive interventions will enable the pet owner to comprehend the pathology, get rid of confusion, and have a healthy attachment in the geriatric period.

Similar to neuropathological aging in humans, a part of the aged dog population shows signs of cognitive dysfunction and dementia. It's critical to differentiate between physiological, cognitive aging, and pathological brain aging at this stage. Behavioral changes in older dogs can be the first indication of deteriorating health and wellbeing, and they can help determine if the animal is aging physiologically or pathologically. (Landsberg 2012; Toepper 2017).

\section{Physiologic Aging Process}

Aging is a natural process that affects every component of the body. In the physiology of aging, there are many metabolic events such as rusting effects of free radicals, telomere shortening, gene effects, and molecular events. Free radical production causes oxidative damage to proteins, lipids, and nucleotides, leading to neuronal dysfunction and eventually death. Oxidative stress is essential for brain function, as it maintains a delicate balance between the development of free radicals and the defense or harm of the brain. The aging of the brain can result in a variety of pathological behavioral and cognitive changes (Rusbridge et al. 2018). Exploring strategies to reduce the harm caused by free radical reactions in humans and animals will reduce morbidity and mortality due to degenerative changes associated with the aging process.

As in humans and all other animals, different behavioral and cognitive features accompany different stages of aging, including changes in the ability to play, concentrate and learn, in dogs according to various life stages and ages (Bature et al. 2017). Studies in laboratory dogs, similar to humans, have reported a decrease in learning, memory, and routine activities with increasing age. The last few studies in pet dogs have reported a reduction in social sensitivity, curiosity for new objects, attention, learning and memory, as age progresses (Adams et al. 2000; Wallis et al. 2014; Wallis et al. 2016). It's a matter of when aging starts in dogs, given such lifelong changes in temperament and cognition. Because there is a large variation in life spans of different dog breeds, aging begins depending on the dog's breed, size, and weight (O'Neill et al. 2013; Szabó et al. 2016). Over the past 200 years, dog breeds are highly inbred, so significant genetic variations have emerged between breeds (Ostrander et al. 2017). Dogs are known to be the most phenotypically diverse mammal species and this difference applies to life span as well as traits such as behavior, morphology, congenital anomalies, disease propensity (Hoffman et al. 2018). So much so that up to two times the difference between species in terms of life span can be observed. Another point that should not be overlooked is the variety of environments where dogs live, food, and care. However, to take an average model, beagles are defined as old middle-aged at 5 to 9 years (human age 40-60) and young before five years old. Although many studies are suggesting that aging begins at the age of seven for Laboratory Beagles, it has been reported that short- term memory disorders start to appear after the age of 6 (Studzinski et al. 2006). On the other hand, (Salvin et al. 2011) reported that even though the aging process progresses along the natural path, in some dogs older than eight years, there is a decrease in response to commands, play, and activity, and even an increase in fear and phobia during these six months. It had been well documented that fear of noises affects the cognitive state in dogs (Karen et al. 2019)

\section{Physiopathology and Clinical Presentation of CDS}

Similar to humans, cognitive dysfunction in dogs results in neuron loss and hyperphosphorylated tau protein (HTP) with amyloid $(A \beta)$ accumulation produced by the breakdown of an excessive $A \beta$ amyloid precursor protein (APP), in the brain parenchyma and blood vessels (Condello and Stöehr 2018). A deposits' volume and extent are related to the degree of cognitive impairment and cause oxidative damage. (DeVos et al. 2018) The histopathological structure in dogs with CDS includes neuropathology with $A \beta$ pathology, decreased brain volume, neuronal loss, and impaired neurogenesis. These deposits, which occur mostly from the age of 8 , settle as widespread plaques in the cortical areas, starting with the prefrontal cortex followed by temporal and occipital cortexes with the hippocampus (Landsberg et al. 2012). Pathological changes in CDS include meningeal calcification, significant demyelination, cerebral cortex and subcortical white matter reduction, lipofuscin augmentation, ventriculomegaly resulting in brain atrophy due to neuronal loss (Heath et al. 2007).

Alzheimer's disease (AD) has closely similar pathogenesis in dogs with cognitive dysfunction. Cortical atrophy, amyloid-B plaque deposition, neuronal loss, altered neurotransmitter function, and reduced neural regeneration have all been observed in dogs. Along with these pathologies altered sleep-wake cycles, social interactions and activity levels are the most common signs that observed (Nešić et al. 2017)

Clinical signs are symbolized under the term DISHA, which refers to the basic symptoms such as disorientation, social deterioration, changes in sleep habits, elimination problems, increased anxiety with changes in activity levels (Landsberg 2012). In experiments testing spatial learning and memory, dogs with cognitive impairment demonstrated a substantial reduction in cognitive abilities (Studzinski et al. 2006). In addition, changes in social sensitivity, such as erratic movement patterns, increased frequency of purposeless behavior, reduced response to the communication, mirror relation, aggression or apathy, anxiety, timidity, not recognizing the owners with circadian rhythm changes are also presented in dogs with CDS (Chapagain et al. 2017; Rosado et al. 2012).

Ozawa et al. (2019) reported new physical signs of CCD, including swaying or falling, smell disturbance, tremor, head ptosis, and vision impairment which must be considered in the geriatric examination (Makiko et al. 2019). The findings of this study demonstrate new signs in the early stage of the disease that may be misevaluated as the signs of physiologic aging.

\section{Diagnosis: Differentiating Between Physiologic Aging} and CDS

Since dog and owner between loyalty is an extremely close relationship, often the owners can detect behavioral differences in their dogs that come with aging, but they attribute them to old age. However, CDS is progressive. Although early diagnosis and treatment do not provide complete recovery, therapeutic attempts have significant 
effects in slowing down the process, providing a higher life quality in the long term. Therefore, correct evaluation of CDS-related findings has prognostic importance. (Romanucci and Della Salda 2015)

The trouble in diagnosis is that there is no confirmed method developed meeting the whole criteria of CDS. The owner assessment is the primary tool to rely on, which has a high potential to be subjective. Several scales based on questionnaires are suggested or scales have been developed (Landsberg et al. 2012; Salvin et al. 2011; Rofina et al. 2006; Yu C-H et al. 2011; González et al. 2011;) but evaluation of the data in these methods are very distinct. (Szabó et al. 2016; Schütt et al. 2015)

According to us, Salvin et al. (2011) scale is the most practical and efficient tool, but the general opinion is that it reflects only severe stages. Canine Dementia Scale (Madari et al. 2015) was designed to describe different stages of CDS. Therefore, methods for laboratory dogs (Adams et al. 2000; Tapp et al. 2003; Wallis et al. 2016; Studzinski et al. 2006; Milgram et al. 2005) may be modified for household pet dogs. In addition, food-seeking (González et al. 2013), or place selection tests (Nagasawa et al. 2012) may be preferred as (Rosado et al. 2012) had demonstrated the effect of CDS stage on locomotion, exploratory behavior, corner-directed (aimless) behaviors, sniffing episodes directed towards the objects and social responsiveness in pet dogs.

In our clinical experience, the scale of (Salvin et al. 2011) is easy to apply for practitioners and provides elementary data. Further scales in combination may be used for the detailed evaluation.

\section{Treatment}

As the general rule, "earlier diagnosis - better prognosis," therefore awareness of the practitioner for CDS in geriatric patients is crucial. It is also very important to inform the owner in detail to obtain optimum collaboration targeting a satisfying treatment response. The owner must know that the signs are not reversible but can be paused or slowed. Indeed, each patient creates its own story, so general expectations may be frustrating.

The current treatment protocol combines three strategies: drug treatment, nutraceuticals and diet, and environmental enrichment. Strict and intense therapy with these strategies generally results in satisfactory clinical outcomes (Landsberg 2012).

\section{Drug therapy}

The main three drugs in the conventional therapy of CCD are Selegiline, Propentofylline, and Nicergoline. They restore the blood flow in brain tissue nearby other therapeutic effects.

Selegiline

Selegiline was the first drug approved by the FDA for dog cognitive disorders and is an irreversible and selective inhibitor of monoamine oxidase B (MAOB) in canines. Selegiline increases enhance dopamine and catecholamine function in the canine brain and improve cognitive function on its own. Improved synaptic impulse transmission could be possible with catecholamine enhancement. Selegiline has an amphetamine-like effect, increasing dopamine release and blocking dopamine reuptake. Selegiline can be the first choice due to its effects on enhancing sleep-wake cycles and social interactions (Landsberg et al. 2012). Recommended dosage in canine CDS is $0.5-1 \mathrm{mg} / \mathrm{kg}$ SID and effects may be expected in 2-8 weeks (Milgram et al. 2002). Augmented impacts could be achieved with a prescription diet. (Dodd et al. 2003)
Propentofylline

Propentofylline improves cerebral blood perfusion, spatial attention, enables nutrient entrance to brain cells, and increases adenosine, elementary for mitochondria. Helps with dullness, lethargy, and depression in dogs (Landsberg et al. 2012). The therapeutic dose for CDS is $2.5-5 \mathrm{mg} / \mathrm{kg}$ BID.

\section{Nicergoline}

Nicergoline acts as an $\alpha-1$ and $\alpha-2$ adrenergic antagonist to increase neuronal conduction, cerebral blood flow, and neuroprotective effects. The therapeutic dose for CDS is 0.25-0.5 mg/kg SID (Siwak et al. 2000).

Unfortunately, there is insufficient research on the effects of canine CDS, so Selegiline is suitable for conventional treatment.

Adrafinil and Modafinil

Adrafinil and Modafinil are noradrenergic systems stimulating drugs. The noradrenergic system aids in the maintenance of alertness, concentration, memory, and learning and neuroprotection. They are prescribed to maintain regular sleep-wake cycles, locomotion, and learning. In dogs, adrafinil introduces increased motility without stereotypic manners at and above $20 \mathrm{mg} / \mathrm{kg}$. Alas, these doses may result in memory loss (Siwak et al. 2000; Dewey 2008; Kelly et al. 2017)

In a study comparing effects in immobility with propentofylline, nicergoline, and adrafinil, the latter was reported to have an improvement in motility, while nickergoline or propentophile did not. The therapeutic dose for adrafinil in CDS is $20 \mathrm{mg} / \mathrm{kg}$ SID. (Siwak et al. 2000).

\section{Memantine}

Memantine is an N-methyl-d-aspartate (NMDA) receptor antagonist, inhibiting glutamate development in CDS patients who have too much glutamine in their system. Memantine is used in AD in humans. In dogs, doses ranging from $0.3-1.0 \mathrm{mg} / \mathrm{kg}$ BID have been used to treat compulsive behaviors (Schneider et al. 2009).

Ropesalazine

In Alzheimer's disease, ropesalazine is used to prevent nerve cell death, the formation of amyloid plaques, and the formation of neurofibrillary tangles. A new drug for dog CDS is being developed by GNT pharma. They suggest that their preliminary studies revealed promising effects in canine dementia, but published data is not available yet.

Antidepressants and Anxiolytics

The use of antidepressants and anxiolytics such as valproic acid, amitriptyline, buspirone, benzodiazepines, fluoxetine, gabapentin, and paroxetine will be essential support in the treatment process since CDS-related neuropathologies may lead to behavioral changes such as nervousness, decreased sensitivity to stimuli, fear, agitation, changing sleep-wake cycles, mood variation, and anxiety. Clomipramine is also a good choice in dogs. (Landsberg 2012)

\section{Dietary and Nutraceutical Treatment}

Antioxidants, vitamin E, and C supplementations were demonstrated to have favorable clinical effects. Vitamins $\mathrm{E}$ and $C$ fight with free radicals and prevents cell integrity. Also, a positive correlation of cognitive ability in CDS with vitamin E supplementation was reported. (Landsberg 2012)

Antioxidants include flavonoids, carotenoids, beta carotene, selenium, and dlalpha-lipoic acid. 
L-carnitine and dl-alpha-lipoic enhance mitochondrial function. Omega-3 fatty promotes cell integrity with considerable anti-inflammatory effects. Hills Prescription diet $\mathrm{R}$ Canine $\mathrm{b} / \mathrm{d} \mathrm{R}$ provided these supplements and had been demonstrated to create improvement in cognitive signs in a couple of months (Dodd et al. 2003).

Thiamine (B1), cobalamin (B12), folate (B9) and pyridoxine (B6) are all essential for neurodevelopment and cognitive function. (Selhub et al. 2010). The same effects are determined in dogs and cats, but vitamin B deficiencies are rare in these species (May and Laflamme 2019).

Medium-chain triglycerides must be a part of the therapy providing glucose for neurons, deteriorating with age. Dietary medium-chain triglycerides (MCTs) can raise blood ketone levels, providing energy for cerebral activity, potentially providing up to $20 \%$ of the brain's energy needs. Diet including 5.5\% MCT given to dogs with CDS resulted in improved cognitive abilities in 8 months (Pan et al. 2011).

L-arginine is a practical antioxidant nearby many other effects. It is metabolized in neurons and body cells, forming citrulline, yielding to nitric oxide (Pan et al. 2013). Nitric oxide modulates vascular tone and blood flow, immune responses, neural communication, and expression of antioxidant enzymes. In addition, the high metabolic activity of the brain requires good perfusion, primarily mediated by nitric oxide (Vauzour et al. 2017).

Phosphatidylserine is a naturally occurring phospholipid that is present in high concentrations in the brain and synapses. It improves memory, learning, and social behavior in dogs and cats by facilitating membranedependent neuronal processes, increasing acetylcholine release, inhibiting muscarinic receptor loss, activating dopamine synthesis and release, and possibly improving memory learning and social behavior. (Osella et al. 2008)

$\mathrm{N}$-acetylcysteine and resveratrol are also very potent antioxidants.

Apoaequorin is a calcium-buffering protein with neuroprotective effects positively influencing learning and attention abilities (May and Laflamme 2019). A recent study demonstrated that $10 \mathrm{mg}$ apoaequorin showed superior performance on cognitive tasks compared with dogs receiving $1 \mathrm{mg} / \mathrm{kg}$ selegiline (Milgram et al. 2015)

S-Adenosyl-l-Methionine (SAMe) is a product of methionine and is essential for liver functions. Exogenous SAMe causes a rise in serotonin turnover and dopamine and norepinephrine levels by raising endogenous glutathione production (May and Laflamme 2019).

Since $95 \%$ of serotonin is gut originated, the link between microbiota and anxiety is apparent, also there is evidence of the effect of gut microbiota in geriatric cognitive deterioration (Bastiaanssen et al. 2019). Therefore, properly capsulated probiotic supports will contribute to clinical satisfaction to the author's experience.

\section{Environmental enrichment}

Environmental enrichment is the irrevocable part of therapy. Studies displayed that enrichment of the environment, toys, exercises, increasing the time spent playing in addition to dietary supplements had a significant positive effect on preventing the symptoms (Milgram et al. 2002; Milgram et al. 2004). Maintaining a regular daily routine contributes to anxiety relief, maintaining brief orientation, and keeping the dog active during daylight hours and sleeping patterns. Adding aromatherapy, tactile and sound cues, such as vocal cues to remind rooms, bed, and routine areas, scent cues like scented candles, and tactile cues like textured matting become the right stimuli.

\section{CONCLUSION}

Geriatric problems are the most challenging period in the dog-owner relationship. For example, in a study, the primary reason for relinquishing dogs to the shelter for euthanasia was the incurable illness of aged dogs (25.77\%) (Vučinić et al. 2009). Dementia and CDS are one of the major frustrating geriatric disorders.

Although it still has many dark sides, CDS is a disease with useful diagnostic and therapeutic strategies available. Veterinarians need to consider this disease in geriatric patients and cooperate by increasing owner awareness, stopping or at least slowing down the disease in elderly dogs, and making the geriatric period more comfortable for both the dog and the owner. As all animal lovers know, not only do they need us, but we also need them, and our mutual responsibility lasts until death.

\section{CONFLICTS OF INTEREST}

The authors report no conflicts of interest.

\section{AUTHOR CONTRIBUTIONS}

Idea / Concept: SR

Supervision / Consultancy: DD

Data Collection and / or Processing: SR

Analysis and / or Interpretation: SR, UBA, BU, DD

Writing the Article: SR

Critical Review: DD

\section{REFERENCES}

Adams B, Chan A, Callahan H, Milgram NW (2000). The canine as a model of human cognitive aging: recent developments. Prog. Neuropsychopharmacol Biol Psychiatry, 24 (5), 675-692.

Bastiaanssen T, Cowan C, Claesson MJ, Dinan TG, Cryan JF (2019). Making Sense of the Microbiome in Psychiatry nt $J$ Neuropsychopharmacol, 22 (1), 37-52.

Bature, F, Guinn, B-A, Pang, D, Pappas, Y (2017). Signs and symptoms preceding the diagnosis of Alzheimer's disease: a systematic scoping review of literature from 1937 to 2016. BMJ Open 7:e015746.

Chapagain D, Virányi Z, Wallis LJ et al. (2017). Aging of attentiveness in border collies and other pet dog breeds: the protective benefits of lifelong training. Front Aging Neurosci, 9, 100.

Condello C, Stöehr J (2018). A $\beta$ propagation and strains: Implications for the phenotypic diversity in Alzheimer's disease. Neurobiol Dis, 109, 191-200.

DeVos SL, Corjuc BT, Oakley DH, et al. (2018). Synaptic Tau seeding precedes Tau pathology in human Alzheimer's disease brain. Front Neurosci, 12:267.

Dewey CW (2008). Encephalopathies: Disorders of the brain. In A Practical Guide to Canine and Feline Neurology, 115-220, ed. C.W. Dewey. Iowa State University Press, Ames, Iowa.

Dodd CE, Zicker SC, Jewell DE (2003). Can a fortified food affect the behavioral manifestations of age-related cognitive decline in dogs? Vet Med Anim Clin, 98, 396.

González-Martínez Á, Rosado B, Pesini P et al. (2011). Plasma $\beta$-amyloid peptides in canine aging and cognitive dysfunction as a model of Alzheimer's disease. Exp Gerontol, 46, 590-596.

Heath SE, Barabas S, Craze PG (2007). Nutritional supplementation in cases of caninecognitive dysfunction-a clinical trial. Appl Anim Behav Sci, 105, 274-283

Hoffman JM, Creevy KE, Franks A, O'Neill DG, Promislow DEL (2018) The companion dog as a model for human aging and mortality. Aging Cell; 17, e12737.

Kelly SC, He B, Perez SE et al. (2017). Locus coeruleus cellular and molecular pathology during the progression of Alzheimer's disease. Acta Neuropathol Commun, 5 (1), 8. 
Landsberg GM, Nichol J, Araujo JA (2012). Cognitive dysfunction syndrome: a disease of canine and feline brain aging. Vet Clin North Am Small Anim Pract, 42, 749-768.

Larsen JA, Farcas A (2014). Nutrition of aging dogs. Vet Clin North Am Small Anim Pract, 44 (4), 741-746.

Madari A, Farbakova J, Katina $S$ et al. (2015). Assessment of severity and progression of canine cognitive dysfunction syndrome using the CAnine DEmentia Scale (CADES). Appl Anim Behav Sci, 171, 138-145.

May K, Laflamme DP (2019). Nutrition and the aging brain of dogs and cats. J Am Vet Med Assoc, 255 (11), 1245-1254.

Milgram NW, Landsberg G, Merrick D, Underwood MY (2015). A nove mechanism for cognitive enhancement in aged dogs with the use of a calcium-buffering protein. J Vet Behav, 10 (3), 217-222

Nagasawa M, Yatsuzuka A, Mogi K, Kikusui T (2012). A new behavioral test for detecting decline of age-related cognitive ability in dogs. $J$ Vet Behav Clin Appl Res, 7, 220-224.

Nešić S, Kukolj V, Marinkoviæ D, Vuèiæeviæ I, Jovanoviæ M (2017) Histological and immunohistochemical characteristics of cerebral amyloid angiopathy in elderly dogs. Vet Q, 37, 1-7.

O'Neill DG, Church DB, McGreevy PD, Thomson PC, Brodbelt DC (2013) Longevity and mortality of owned dogs in England. Vet J, 198 (3), 638643.

Osella MC, ReG, Badino P (2008). Phosphatidylserine (PS) as a potential nutraceutical for canine brain aging: a review. J Vet Behav Clin Appl Res, 3 (2), 41-51.

Ostrander EA Wayne RK, Freedman AH,Davis BW (2017). Demographic history, selection and functional diversity of the canine genome. Nat Rev Genet, 18, 705- 720.

Overall KL, Dunham AE, Scheifele P, Malowski KS (2019). Fear of noises affects canine problem-solving behavior and locomotion in standardized cognitive tests. Appl Anim Behav Sci, 221, 104863.

Ozawa $M$, Inoue $M$, Uchida $K$ et al. (2019). Physical signs of canine cognitive dysfunction. J Vet Sci,81 (12), 1829-1834.

Pan Y (2011). Enhancing brain functions in senior dogs: a new nutritional approach. Top Companion Anim Med, 26 (1), 10-16.

Pan Y, Araujo JA, Burrows J et al. (2013). Cognitive enhancement in middle-aged and old cats with dietary supplementation with a nutrient blend containing fish oil, B vitamins, antioxidants and arginine. $\mathrm{Br} J$ Nutr, 110 (1), 40-49.

Rofina JE, van Ederen AM, Toussaint MJM et al. (2006). Cognitive disturbances in old dogs suffering from the canine counterpart of Alzheimer's disease. Brain Res 1069, 216-226.

Romanucci M, Della Salda L (2015). Oxydativestress and protein quality control systems in the aged canine brain as a model for human neurodegenerativedisorders. Oxidative Medicine and Cellular Longevity, Hindawi Publishing Corporation, London.

Rosado B, González-Martínez Á, Pesini P et al. (2012). Effect of age and severity of cognitive dysfunction on spontaneous activity in pet dogs. 1. Locomotor and exploratory behaviour. Vet J, 194, 189-195.
Rusbridge C, Salguero FJ, David MA et al. (2018). An aged Canid with behavioral deficits exhibits blood and cerebrospinal fluid amyloid beta oligomers. Front. Aging Neurosci, 10, 7.

Salvin HE, McGreevy PD, Sachdev PS, Valenzuela MJ (2011). Growing old gracefully - behavioral changes associated with "successful aging" in the dog, Canis familiaris. J Vet Behav Clin Appl Res, 6, 313-320.

Schmidt F, Boltze J, Jäger C et al. (2015). Detection and Quantification of $\beta$-Amyloid, Pyroglutamyl $A \beta$, and Tau in Aged Canines. J Neuropathol Ex Neurol, 74 (9), 912-923.

Schneider BM, Dodman NH, Maranda L (2009). Use of memantine in treatment of canine compulsive disorders. J Vet Behav, 4 (3), 118-126.

Schütt T, Toft N, Berendt M (2015). A comparison of 2 screening questionnaires for clinical assessment of canine cognitive dysfunction. J Vet Behav Clin Appl Res, 10, 452-458.

Selhub J, Troen A, Rosenberg IH (2010). B vitamins and the aging brain. Nutr Rev, 68, 112-118.

Siwak CT, Gruet P, Woehrle F et al. (2000). Behavioral activating effects of adrafinil in aged canines. Pharmacol Biochem Behav, 66, 293-300.

Studzinski CM, Christie LA, Araujo JA et al. (2006). Visuospatial function in the beagle dog: an early marker of cognitive decline in a model of human aging and dementia. Neurobiol Learn Mem, 86, 197-204.

Szabó D, Gee NR, Miklósi Á (2016). Natural or pathologic? Discrepancies in the study of behavioral and cognitive signs in aging family dogs. J Vet Behav Clin Appl Res, 11, 86- 98.

Tapp PD, Siwak CT, Estrada J, Holowachuk D, Milgram NW (2003) Effects of age on measures of complex working memory span in the beagle dog (Canis familiaris) using two versions of a spatial list learning paradigm. Learn Mem, 10, 148-160.

Toepper M. (2017). Dissociating Normal Aging from Alzheimer's Disease: A View from Cognitive Neuroscience. Journal of Alzheimer's disease: $J A D, 57$ (2), 331-352.

Vauzour D, Camprubi-Robles M, Miquel-Kergoat $S$ et al. (2017) Nutrition for the ageing brain: Towards evidence for an optimal diet. Ageing Res Rev, 35, 222-240.

Vučinić M, Đorđević M, Teodorović R et al. (2009). Reasons for relinquishment of owned dogs in a municipal shelter in Belgrade. Acta Vet-Beograd, 59 (2-3), 309-317.

Wallis L, Range F, Müller C et al. (2014). Lifespan development of attentiveness in domestic dogs: drawing parallels with humans. Front Psychol, 5, 71.

Wallis LJ, Virányi Z, Müller CA et al. (2016). Aging effects on discrimination learning, logical reasoning and memory in pet dogs. Age, 38 (1), 6.

Yu CH, Song GS, Yhee JY et al. (2011). Histopathological and immunohistochemical comparison of the brain of human patients with Alzheimer's disease and the brain of aged dogs with cognitive dysfunction. J Comp Pathol, 145, 45-58. 